\title{
Spanish validation of the Parental Psychological Control Scale and Parental Psychological Control- Disrespect Scale
}

\author{
Carmen Rodríguez-Menéndez; $\mathbf{M}^{\mathrm{a}}$ de las Mercedes Inda-Caro; \\ Carmen $\mathbf{M}^{\mathrm{a}}$ Fernández-García; Lindsay Martínez-García
}

How to cite this article:

Rodríguez-Menéndez, C., Inda-Caro, M., de las M., Fernández-García, C., M., \& Martínez-García, L. (2021). Spanish validation of the Parental Psychological Control Scale and Parental Psychological Control-Disrespect Scale. Acta Colombiana de Psicología, 24(1), 107-120. https:/www.doi.org/10.14718/ACP.2021.24.1.10

Recibido, septiembre 17/2019; Concepto de evaluación, enero 24/2020; Aceptado agosto 25/2020

\author{
Carmen Rodríguez-Menéndez ${ }^{1}$ \\ ORCID: https://orcid.org/0000-0001-7074-8223 \\ Universidad de Oviedo, Oviedo, España. \\ $M^{a}$ de las Mercedes Inda-Caro \\ ORCID: https://orcid.org/0000-0003-4752-3258 \\ Universidad de Oviedo, Oviedo, España. \\ Carmen $\mathbf{M}^{\mathrm{a}}$ Fernández-García \\ ORCID: https://orcid.org/0000-0001-6314-355X \\ Universidad de Oviedo, Oviedo, España. \\ Lindsay Martínez-García \\ ORCID: https://orcid.org/0000-0003-0650-7112 \\ Universidad de Oviedo, Oviedo, España.
}

\begin{abstract}
The construct "parental psychological control" has been used to refer to those parental behaviors that interfere with the children's thoughts and feelings. Examples of this type of behaviors would be inducing guilt or shame as well as the withdrawal of affection. The objective of this study was to validate and adapt the Spanish version of the Psychological Control Scale-Youth Self-Report (PCS-YSR) and the Psychological Control-Disrespect Scale (PCDS) and to analyze if the parental psychological control is defined as one dimension or two dimensions through manipulative and disrespectful behaviors towards adolescents. Also, the unique contribution of parental psychological control in predicting adolescent's self-concept was examined. In two samples of undergraduate university students (the first, $\mathrm{N}=367$, mean age $=19.8$, women $=62.7 \%$, men $=37.3 \%$, and the second, $\mathrm{N}=312$, mean age $=19.7$, women $=73.9 \%$, men $=26.1 \%$ ), exploratory and confirmatory factor analyses confirmed the hypothesized factor structure of the PCS-YSR and the PCDS, for both paternal and maternal ratings. Convergent validity was confirmed by consistent associations between both measures of parental psychological control and other measures of parental autonomy support and parental psychological control. The multi-group analysis confirmed that parental psychological control had a negative influence on self-concept. The results indicated that both scales are useful instruments for assessing parental psychological control.

Keywords: psychometrics, reliability, cross-cultural, late adolescents, parental psychological control.
\end{abstract}

1 C/Aniceto Sela s.n. Facultad de Formación del Profesorado y Educación Despacho 322, c.p. 33006. Número de teléfono: +34985102857 , carmenrm@uniovi.es 


\title{
Validación española de la Escala de Control Psicológico Parental y la Escala Control Psicológico-Falta de Respeto
}

\begin{abstract}
Resumen
El constructo "control psicológico parental" se ha utilizado para referirse a los comportamientos de los progenitores que interfieren con los pensamientos y sentimientos de los niños y niñas. Ejemplos de este tipo de comportamientos son la inducción de culpa o vergüenza, así como la retirada de afecto. Nuestro estudio tuvo como objetivo validar y adaptar la versión española de la Escala de Control Psicológico-Autoinforme Adolescente (PCS-YSR) y la Escala Control Psicológico-Falta de Respeto (PCDS), y analizar si el control psicológico parental se define como una dimensión o dos dimensiones a través de conductas manipuladoras e irrespetuosas hacia los adolescentes. Además, examinamos la contribución única del control psicológico parental en la predicción del autoconcepto del adolescente. En dos muestras de estudiantes universitarios de pregrado (la primera $\mathrm{n}=367$, edad media $=19.8$, mujeres $=62.7 \%$, hombres $=37.3 \%$, y la segunda, $\mathrm{n}=312$, edad media $=19.7$, mujeres $=73.9 \%$, hombres $=26.1 \%$ ), los análisis factoriales exploratorios y confirmatorios confirmaron la estructura factorial hipotética del PCS-YSR y del PCDS, tanto para las puntuaciones paterna como materna. La validez convergente fue confirmada por asociaciones consistentes entre ambas medidas de control psicológico parental y otras medidas de apoyo parental a la autonomía y control psicológico parental. El análisis multigrupo confirmó que el control psicológico de los progenitores influyó negativamente en el autoconcepto. Los resultados indicaron que ambas escalas son instrumentos útiles para evaluar el control psicológico parental.

Palabras clave: psicometría, fiabilidad, transcultural, adolescentes tardíos, control psicológico parental.
\end{abstract}

\section{Conceptualizing psychological control}

In past decades, research showed that the construct "parental control" was ambiguous because it was used in different and contradictory ways. This heterogeneity in the meaning of the construct had a direct effect on the results obtained in the research, which have been very different and inconsistent (Bean et al., 2006). In this context, Barber (1996) proposed to differentiate between "behavioral control" and "psychological control" and developed different scales to measure these constructs. Psychological control refers to those parental behaviors that interfere with the children's thoughts and feelings. In this sense, Barber and Harmon (2002) explain that psychological control can be manifested through different parental behaviors and tactics: a) guilt induction, that refers to the use of guilt to get children to do what the parents want, b) love withdrawal, which refers to the use of love and care as a reward or punishment to get children to adapt to the parental expectations, c) induction of anxiety to get children to do what the parents want, and d) invalidation of the children's perspective, which refers to the constraint of the children's spontaneous expression of thoughts, wishes and feelings. Thus, psychological control would be particularly related to personality problems, such as low self-esteem and depression.

To measure psychological control, Barber (1996) constructed a scale with 16 items, which measured different aspects of psychological control: constraining verbal expression, invalidating feelings, personal attack, guilt induction, love withdrawal, and erratic emotional behavior. Those 16 items were submitted to factor analysis and eight of them formed a single factor (psychological control). These eight items constituted the final version of the scale. The scale was labeled the Psychological Control Scale-Youth Self Report (PCS-YSR). Barber (1996) confirmed the validity and predictability of this scale, demonstrating that PCS-YSR was a good instrument to measure psychological control.

Barber et al., (2012) developed a new conceptualization of the psychological control construct which includes parents' disrespect behavior. So it is established that psychological control has three components: The first one of them is manipulation and coercion, understanding that psychological control manipulates or dominates the child for the sake of parental demands or expectations; the second component is the intrusion into the children personal domain; and the third component is disrespect.

This new conceptualization was submitted to empirical validation using a combination of qualitative and quantitative methodology (Barber et al., 2012). First, in the qualitative phase, focus groups were conducted with several youths from five cultures. Researchers asked them to identify manipulative and coercive parental behaviors. Then, in the quantitative phase, key exemplars of eight domains of psychological control, -that were indicated by youths in focus groups- were used to create items for a survey administered to 2100 youths: ridiculing, embarrassing in public, invalidating, violation of privacy, induction of guilt, excessive expectations, comparing to others, and 
ignoring. These eight domains were grouped into eight items that Barber et al., (2012) called "Psychological Control-Disrespect Scale" (PCDS). It was found that this scale was psychometrically distinct from the PCS-YSR scale because confirmatory analyses indicated that the model fit better when both scales were kept separate. In addition, it was concluded that the PCDS functioned more effectively than the PCS-YSR because the PCDS accounted for all and more of the variance in adolescents' outcomes (Barber et al., 2012).

Several studies have been done to analyze the influence of psychological control, measured through PCS-YSR in children's and adolescents' adjustment. Traditionally, results of cross-cultural and longitudinal studies showed that perceived psychological control had a positively association with internalizing problems, although there were differences between the influence of mothers' and fathers' psychological control (Aunola et al., 2013; Barber et al., 2005; Lansford et al., 2014; Mabbe et al., 2016; Rogers et al., 2003). Specifically, a significant number of studies have revealed that psychological control - or some specific dimensions of psychological control measured through PCS- YSR- have an influence on the development of certain depressive symptoms (Ahmad and Soenens, 2010; Barber 1996; Barber et al., 2005; Rogers, Padilla-Walker, McLean, and Hurst, 2020; Romm, Metzger, and Alvis, 2020; Rudy et al., 2008), adolescent dependency and adolescent criticism (Ahmad and Soenens, 2010), low self-esteem (Bean and Northrup 2009; Özdemir, 2012; Soenens et al., 2005), low academic performance (Lu et al., 2018), under-eating behaviors (Romm \& Metzger, 2018; Rommet al., 2020), fear of failure (Deneault, Gareau, Bureau, Gaudreaua, \& Lafontaine, 2020), and substance abuse (Romm \& Metzger, 2018; Romm et al., 2020). Also, in the study by Hunter, Barber, and Stolz (2015), adolescents' self-esteem mediated the association between maternal and paternal psychological control and both adolescent depression and antisocial behavior.

In addition, other studies- have also found correlations between psychological control, measured through PCS-YSR, and externalizing problems (Arim \& Shapka, 2008; Barber 1996; Lansford et al., 2014; Mabbe et al., 2016; Márquez et al., 2014; Rogers et al., 2003), particularly in physical, overt, and relational aggression, influencing directly (Casas et al., 2006; Loukas et al., 2005; Soenens et al., 2008) or through the mediating role of other dimensions, such as emotion regulation (Blossom et al., 2016; Cui et al., 2014).

\section{The current study}

The present instrumental study (Ato, López \& Benavente, 2013) aimed to validate and adapt the Spanish version of the Psychological Control Scale Youth Self-Report (PCSYSR) and the Psychological Control-Disrespect Scale (PCDS) with Spanish late adolescents. Both scales have been validated in the United States with demographically varied samples (Barber, 1996; Barber et al., 2012; Romm et al., 2020) and this study intends to contribute to their validation and adaptation to the Spanish context, which has a different linguistic and cultural background. It is important to contribute to this validation in another cultural context because parental psychological control may show similarity across cultural groups. This is because psychologically controlling parenting frustates children's basic need for autonomy which refers to the experimentation of a sense of volition and choice when a person performs an activity (Soenens et al., 2012). Therefore, when this basic need is frustrated, the person experiences a sense of pressuring to act, think, or feel in a particular way. For these reasons, it is interesting to study another culture to test the universalism perspective in relation to the parental psychological control. Thus, the present study assessed the factorial and convergent validity and reliability of the PCS-YSR and PCDS with two samples of Spanish late adolescents. In PCS-YSR, psychological controlling parenting was operationalized through manipulative behaviors, such as (a) invalidating feelings, (b) constraining verbal expressions, (c) personal attack, and (d) love withdrawal. In PCDS, psychological control was operationalized as disrespect behaviors such as (a) ridiculing, (b) embarrassing in public, (c) invalidating, (d) violation of privacy, (e) induction of guilt, (f) excessive expectations, (g) comparing to others, and (h) ignoring.

In sum, it was expected to replicate the structure of both scales concluding that PCS-YSR scale was psychometrically distinct from the PCDS scale. Furthermore, it was expected to find different patterns of associations between PCS-YSR/ PCDS and other measures of family dimensions: parental psychological control and parental autonomy support. In this sense, it had been hypothesized that PCS-YRS and PCDS would be positively correlated to other measures of psychological control and would be negatively correlated to parental autonomy support, in similar way to other studies (Mantzouranis et al., 2012; Soenens et al., 2010; Soenens et al., 2012). In addition, the correlations between perceived psychological control and late adolescent's self-concept were also examined to contribute to the research that studies the influence of psychological control in adolescent's adjustment. It was expected that both mothers' and fathers' perceived psychological control would have a negative influence on late adolescent's self-concept. 
110

Method

\section{Participants}

A convenience sampling technique was used due to the fact that there was no manipulation of criterion variables and that participants had been randomly allocated into each group. All the participants belonged to the target population. Therefore, all of them fulfilled the needed criteria to be enrolled in the study: being late adolescents. The participants were distributed into two samples from different campuses of the same Spanish university. The first one consisted of 367 undergraduate students. Over half of them (230) were women (62.7\%) and 137 were men (37.3\%) (One student failed to indicate their sex). The second sample comprised 312 undergraduate students, $73.9 \%$ women and $26.1 \%$ men. Both samples had the same mean age, the first one had a mean age of $19.80, S D=2.11$, and in the second sample the mean age was $19.70, S D=2.91$ Each participant had to assess their parents (mother and father) by responding some questions about their progenitors. As a consequence, the sample was duplicated: for the first sample, the data could go up to 734, and in the second sample, up to 624 answers. A random sampling was used to choose the participants among students from a Spanish University.

It should be noted that the population samples in which the scales were originally applied and in which we have carried out the present study have important cultural and linguistic differences. First, English is the mother tongue of the initial sample and Spanish is the mother tongue of the sample in which the adaptation was made. In addition, in this study, unlike the initial samples in which the scales were originally applied, the sample was very homogeneous about ethnicity due to the fact that there was not much ethnic diversity in Asturias, as it is a Spanish region with a low number of immigrants.

\section{Instruments}

Psychological Control Scale (PCS-YSR) (Barber, 1996). This scale consists of 8 Likert items. The conceptual dimension refers to the attempt of parents to monitor the children's feelings and emotions. Controlling parenting was operationalized as invalidating feelings, constraining verbal expressions, personal attacks, and love withdrawal. The alpha value in the original version was .83 for answers about the mother's version, and .82 for replies about the father's behaviors. As regards of discriminant validity the values were -.13 for divergent validity, whereas the convergent one got a value of .34 (Barber et al., 2012)

Psychological Control-Disrespect Scale (PCDS) (Barber et al., 2012). This scale consists of eight Likert items. The construct core is the ability of parents to control their children using manipulation, coercion and a wrong exercise of parenthood. Psychological control was operationalized as ridiculing, embarrassing in public, invalidating, violation of privacy, induction of, excessive expectations, comparing to others, and ignoring. The original version obtained good fit indexes. In both scales items were rated on a 3-point Likert scale ranging from 1 (Not like her/him) to 3 (A lot like her/him). Participants rated the items separately for each parent. In the original version the alpha values were .83 for mothers and .90 for fathers; being the construct validity values of .66 for convergent validity and -.34 for the divergent one (Barber et al., 2012).

Dependency-Oriented and Achievement-Oriented Psychological Control Scale (DAPCS) (Soenens et al., 2010). This is a 17-items questionnaire which assesses two types of psychological control: dependency-oriented and achievement-oriented. Dependency-oriented psychological control was measured with eight items; this concept refers to the parents' psychological control to keep their children close, and achievement-oriented psychological control, with nine items. Control is defined as the psychological regulation used by parents as a way to get their children behave according to their standards (Soenens et al., 2010). The items were rated on a 5 -point Likert scale, ranging from 1 (strongly disagree) to 5 (strongly agree). The alpha values in the original version were .93 for mother's ratings and .91 for father's ratings (Soenens et al., 2010). In the Spanish version the alpha values were .92 for replies about fathers, and. 89 for answers about mothers' behaviors (García-Pérez, Rodríguez-Menéndez, Torío-López \& Pérez-Rodríguez, 2019). The validity indexes were between .55 and .71 in the original version for convergent validity (Soenens et al., 2010) and for divergent validity the values were -.10 and -.50 . In the Spanish version the indexes were between .48 and .65 with respect to convergent validity, and regarding divergent one were -.27, and -.61 (García-Pérez et al., 2019).

Perceived Parental Autonomy Support Scale (P-PASS) (Mageau et al., 2015). This instrument consists of 24 items assessing adolescents' perception about their parents' use of autonomy support versus controlling behaviors. The P-PASS measures three parental autonomy supportive behaviors and three controlling parenting behaviors. So, autonomy supportive strategies are provision of choice with certain limits, rationale for demands and limits, and acknowledgement of feelings Controlling parenting behaviors are threats to punish, performance pressures, and guilt-inducing criticisms. Adolescent participants rated each item on a 7-Likert scale, first regarding the mother and second, the father $(1=$ Do not agree at all to $7=$ Very strongly agree). Parental autonomy support was measured 
with 12 items. Controlling parenting behaviors were measured through 12 items. Reliability in the original version was .89 , for mothers and fathers. The discriminant validity took values between .33 and .57 for convergent validity and -.22 and -.62 for the divergent one. In the Spanish version the alpha values were .97 for fathers and .98 for mothers in autonomy support; and .93 for fathers and .94 for mothers in parental control. The values of divergent validity were between -.31 and .55; and regarding convergent validity, these were between .13 and .58 .

AF5. Autoconcepto Forma 5 (García \& Musitu, 1999). This self-report is a Spanish instrument which assesses a person's self-concept in five aspects: social, academic/work life, emotional, family, and physical. The social self-concept assesses the perception of the person about his or her social networks and the personality traits in social relationships. With respect to academic/work life self-concept, the test measures the self-perception as worker or student emotionally and efficiently. Furthermore, it gets information about the subject's insight on how are their family relationships. Additionally, the emotional dimension of self-concept values the inner life and its influence on the personal relationships. Finally, the physical self-concept evaluates how the person perceives oneself regarding the physical condition and appearance. Participants answered 30 items with values between 1 and 99, depending on the level of agreement with the statement. The reliability of the overall scale is .82; and for each self-concept is, respectively: academic/ professional life, $\alpha=.88$; social, $\alpha=.70$; emotional, $\alpha=.73$; family, $\alpha=.77$ and physical, $\alpha=.74$.

\section{Procedure}

Questionnaires were administrated during class time in the second semester of the academic year. After a brief presentation in which the researcher described the purpose of the study, the students were invited to fill out the questionnaires. If students did not want to participate in the study, they could leave the classroom but most of them agreed to participate in the research. The questionnaires were administered after obtaining permission from the college management. The study was not previously approved by any ethics committee because it was not necessary to do it in our region. Participants did not receive any remuneration for their participation. The questionnaire took about $25 \mathrm{mi}-$ nutes to complete. Anonymity of answers was guaranteed.

To get a right content validity all scales were translated from the English version into Spanish. Three members of the research team, who were experts in parental psychological control, were responsible for developing an initial Spanish translation of the original version. Once finished, this initial version was assessed by two experts in parenting styles from the University of Oviedo, who evaluated whether the items reflected the daily dynamics of Spanish families. Previously, they were informed of the psychometric characteristics of the scales, as well as the characteristics of the population in which the scales were to be applied and the place where their application would take place. Then a bilingual translator, who did not have prior knowledge of the original versions, back translated the Spanish versions.

\section{Data analysis}

The AERA, APA \& NCME (1985, p.13) point at the standard 1.1. that multiple evidence of validity should be presented. To achieve this goal, the first step considered the establishment of a theoretical framework which defined the construct of interest. The study also developed diverse stages of validity following AERA, APA \& NCME (1985). Furthermore, in order to guarantee its reliability and validity, 13.4 points are required when a test is translated into another language (AERA, APA \& NMCE, 1999, p.99, cited in Hambleton, Merenda \& Spielberger, 2005).

Firstly, as construct-related evidence was run an exploratory factor analyses (EFA) and confirmatory factor analysis (CFA) were carried out to PCS-YSR and PCDS separately for fathers and mothers. First, it was checked whether the data were suitable for EFA and CFA: normality of sample (skewness, kurtosis). The EFA, first sample, was performed using the Factor program (Ferrando \& Lorenzo-Seva, 2017). The normality of the sample was assessed (skewness, kurtosis) and Bartlett's and KaiserMeyer-Olkin's (KMO) indexes were calculated. The scree plot and "minimum partial test" were used to determine how many factors were retained. Unweighted least squares were used as factor extraction method. This method has proven to be the most effective one with relatively small samples (Ferrando \& Anguiano-Carrasco, 2010). Promin was the oblique rotation method employed (Lorenzo-Seva, 1999), because it does not consider factors as pure measures of a single dimension. With the second subsample, a confirmatory factor analysis was performed (CFA) using the MPLUS 7.3 software (Muthén \& Muthén, 1998; 2012). In order to test the structure given by the EFA, Maximum Likelihood was the estimation method selected. The CFA fit measures included: The Chi-Square test of significance $\left(\chi^{2}\right)$, the Tucker Lewis index-non normed fit index (TLINNFI), the comparative fit index (CFI), Steiger's Root Mean Square error of approximation (RMSEA) and the Standardized Root Mean Square Residual (SRMR).

In addition, the Item Response Theory was used to analyze the differential analysis of items and deepen the 
112

role of each reactive in the construct validity of instruments through the IRTPRO software 4.2 (Scientific Software International, 2017. For each item, the difficulty level, the discrimination index through the slope values, and the fit index were calculated.

Likewise, the convergent and divergent validity were examined in order to distinguish the construct analyzed in the study from other control types, as pointed out in standard 1.8 (AERA, APA \& NCME, 1985). The criterion-related evidence was ensured with the Pearson's correlations between PCS-YSR, PCDS, DAPCS, P-PASS scales and, the regression analyses model with these variables and student's self-concept as criterion variable.

To advance in the validity generalization, all the analyses were performed for mothers' and fathers' samples separately. AERA, APA \& NCME (1985) point out the need to develop a validity process with different settings. Consequently, both instruments were answered thinking of their father and mother independently.

\section{Results}

\section{Internal Consistency}

The values obtained were Bartlett's statistic $=2,235.3$, $d f=120, p=.000010$, and $\mathrm{KMO}=.92$. Likewise, the skewness and kurtosis values in the items ranged from 1.48 to -1.77 in skewness, and from 1.38 to -0.90 in kurtosis. Analyses began regarding both scales as part of the same questionnaire, considering the PCS-YSR and PCDS underlying one dimension: psychological control. The fit model measures included: the Chi-Square significance test $\left(\chi^{2}\right)$, the Tucker Lewis index-Non normed fit index (TLINNFI), the comparative fit index (CFI), the goodness of fit index (GFI), Root Mean Square of Residuals (RMSR), Standardized Root Mean Square Residual (SRMR), and
Steiger's Root Mean Square error of approximation (RMSEA).

The first EFA could suggest one factor for mothers and fathers (Table 1). The alpha value in one- dimension model for mothers was .88; regarding fathers, the internal consistency was .91. As table 1 shows, the fit indexes were accurate, mainly for fathers. Specifically, another factor analysis was done, considering two domains. The factor analysis produced solutions with good fit indices, but not with an adequate structure model. Concerning fathers' ratings, items 5, 6, 14 y 15 loaded in one factor $(\alpha=.87)$, and the rest of items gathered in another factor $(\alpha=.91)$. About mothers' assessment, the two domains solution behaved in a similar way: one factor with items 7, 8 and $14(\alpha=.81)$, and a second factor with an alpha of 90 .

Furthermore, it was considered that there could be an independence between the PCS-YSR and PCDS scales. To test this hypothesis, an EFA was run for PCS-YSR, and another one for PCDS. Table 1 depicts fit indices values: for PCS-YSR, fathers got a .83 in Cronbach value, with regard to mothers, and the Cronbach value was .76. Considering PCDS alpha values, these were .85 for fathers, and .83 for mothers. These four EFAs got good fit; the incremental indexes (TLI and CFI) are better in PCDS when they are considered independently from PCS-YSR (Table 1), as fathers and mothers. However, the PCS-YSR data are not clear, particularly for mothers. Regarding absolute indices (GFI and RMSR), the values shows the best fit when PCSYSR and PCDS are considered individually.

Table 2 represents the standardized factor loadings in each scale, by parents' gender. About PCS-YSR, item 6 had a higher value for fathers than for mothers, followed by item 4 for fathers and item 5 for mothers. Regarding PCDS, the items with the highest loadings were the same for fathers and mothers; item 3 was the one with the highest value; however, item 1 was the second with a higher value in mothers.

Table 1

Summary of Exploratory Factor Analysis

\begin{tabular}{lccccccc}
\hline & $\chi^{2}$ & $d f$ & $p_{\text {value }}$ & TLI-NNFI & CFI & GFI & RMSR \\
\hline PCS-YSR \& PCDS One Fathers domain & 155.31 & 104 & .001 & .99 & .99 & .98 & .06 \\
PCS-YSR \& PCDS One Mothers domain $^{210.72}$ & 104 & .000 & .97 & .98 & .96 & .07 \\
PCS-YSR Fathers & 41.10 & 20 & .004 & .98 & .98 & .97 & .06 \\
PCS- YSR Mothers & 75.64 & 20 & .000 & .90 & .93 & .97 & .08 \\
PCDS Fathers & 41.01 & 20 & .004 & .98 & .99 & .99 & .06 \\
PCDS Mothers & 46.87 & 20 & .007 & .98 & .98 & .98 & .06 \\
\hline
\end{tabular}

Note. $d f=$ degrees of freedom, TLI-NNFI $=$ Tucker Lewis Index - Non-normed Fit Index; CFI = comparative fit index, GFI = goodness of fit index, RMSR= Root Mean Square of Residuals, PCS-YSR = Psychological Control Scale, PCDS = Psychological Control-Disrespect Scale. 
Table 2

Factor loadings for Psychological Control Scale (PCS-YSR) and Psychological Control-Disrespect Scale (PCDS) reliability. Upper values slash from fathers and lower slash from mothers $(F / M)$

\begin{tabular}{|c|c|c|c|c|}
\hline Items & Loadings & Mean & Variance & Alpha \\
\hline Psychological Control Scale (PCS-YSR) & $(\mathrm{F} / \mathrm{M})$ & $(\mathrm{F} / \mathrm{M})$ & $(\mathrm{F} / \mathrm{M})$ & $.83 / .76$ \\
\hline \multicolumn{5}{|l|}{ My Mother or Father is a person who... } \\
\hline $\begin{array}{l}\text { 1. Siempre intenta cambiar cómo me siento o pienso con respecto a las cosas [Is always } \\
\text { trying to change how I feel or think about things] }\end{array}$ & $.60 / .53$ & $1.37 / 1.40$ & $0.37 / 0.38$ & \\
\hline $\begin{array}{l}\text { 2. Cambia de tema cuando tengo algo que decir [Changes the subject whenever I have } \\
\text { something to say] }\end{array}$ & $.46 / .49$ & $1.21 / 1.22$ & $0.24 / 0.26$ & \\
\hline 3. A menudo me interrumpe [Often interrupts me] & $.52 / .58$ & $1.37 / 1.47$ & $0.41 / 0.46$ & \\
\hline $\begin{array}{l}\text { 4. Me culpa a mí de los problemas de otros miembros de la familia [Blames me for other } \\
\text { family members' problems] }\end{array}$ & $.64 / .58$ & $1.15 / 1.19$ & $0.21 / 0.26$ & \\
\hline $\begin{array}{l}\text { 5. Cuando él/ella me critica, saca a la luz errores que cometí en el pasado [Brings } \\
\text { up past mistakes when s/he criticizes me] }\end{array}$ & $.60 / .66$ & $1.47 / 1.66$ & $0.52 / 0.62$ & \\
\hline $\begin{array}{l}\text { 6. Si no veo las cosas como él /ella las ve es menos amistoso conmigo [Is less friendly } \\
\text { with me if I do not see things her/his way] }\end{array}$ & $.81 / .73$ & $1.32 / 1.26$ & $0.42 / 0.32$ & \\
\hline $\begin{array}{l}\text { 7. Evita mirarme cuando lo/la decepciono [will avoid looking at me when I have disap- } \\
\text { pointed her/him] }\end{array}$ & $.42 / .42$ & $1.39 / 1.38$ & $0.44 / 0.43$ & \\
\hline $\begin{array}{l}\text { 8. Si hiero sus sentimientos, me deja de hablar hasta que hago algo que lo/la complazca } \\
\text { (agrade)[If I have hurt her/his feelings, stops talking to me until I please her/him } \\
\text { again] }\end{array}$ & $.32 / .55$ & $1.41 / 1.51$ & $0.42 / 0.49$ & \\
\hline Psychological Control-Disrespect Scale (PCDS) & & & & $.85 / .83$ \\
\hline \multicolumn{5}{|l|}{ My Mother or Father is a person who... } \\
\hline $\begin{array}{l}\text { 1. Me ridiculiza o me hace de menos* (Ejemplo: Diciendo que soy estúpido, in- } \\
\text { útil...) [Ridicules me or puts me down (e.g. saying I am stupid, useless, etc.)] }\end{array}$ & $.44 / .69$ & $1.26 / 1.22$ & $0.62 / 0.28$ & \\
\hline $\begin{array}{l}\text { 2. Me avergüenza en público (Ejemplo: Delante de mis amigos/as...) [Embarrasses me } \\
\text { in public (e.g. in front of my friends)] }\end{array}$ & $.44 / .57$ & $1.10 / 1.15$ & $0.13 / 0.21$ & \\
\hline $\begin{array}{l}\text { 3. No me respeta como persona (Ejemplo: No me deja hablar, favorece a otros antes que } \\
\text { a mi...) [Doesn't respect me as a person (e.g. not letting me talk, favoring others over } \\
\text { me, etc.)] }\end{array}$ & $.56 / .62$ & $1.11 / 1.15$ & $0.14 / 0.20$ & \\
\hline $\begin{array}{l}\text { 4. Viola mi intimidad (Ejemplo: Entra en mi habitación, fisga en mis cosas (se mete en } \\
\text { mis asuntos)) [Violates my privacy (e.g. entering my room, going through my things, } \\
\text { etc.)] }\end{array}$ & $.37 / .53$ & $1.15 / 1.52$ & $0.18 / 0.47$ & \\
\hline $\begin{array}{l}\text { 5. Intenta hacerme sentir culpable por cualquier cosa que he hecho o que él/ella quiere } \\
\text { que haga [Tries to make me feel guilty for something I've done or something s/he } \\
\text { thinks I should do] }\end{array}$ & $.75 / .72$ & 1.301 .39 & $0.39 / 0.43$ & \\
\hline $\begin{array}{l}\text { 6. Espera demasiado de mí (Ejemplo: Hacerlo mejor en el colegio, ser mejor } \\
\text { persona...) [Expects too much of me (e.g. to do better in school, to be a better } \\
\text { person, etc)] }\end{array}$ & $.37 / .45$ & $1.60 / 1.65$ & $0.49 / 0.50$ & \\
\hline $\begin{array}{l}\text { 7. A menudo injustamente me compara con otros (Ejemplo: Con mi hermano, } \\
\text { hermana, con él/ella) [Often unfairly compares me to someone else (e.g. to my } \\
\text { brother or sister, to her/himself)] }\end{array}$ & $.48 / 61$ & $1.36 / 1.61$ & $0.42 / 0.59$ & \\
\hline $\begin{array}{l}\text { 8. A menudo me ignora (Ejemplo: Evitándome, no prestándome atención...) [Often } \\
\text { ignores me (e.g. walking away, from me, not paying attention to me)] }\end{array}$ & $.41 / .24$ & $1.19 / 1.16$ & $0.25 / 0.24$ & \\
\hline
\end{tabular}

As EFA did not reveal clear solutions, a confirmatory factor analysis considering one and two domains, respectively, was conducted for the definition of psychological control. Analyses were run separately for fathers and mothers. Considering fathers, $n=285$ (there were 27 missing values) the two- dimension model got the best fit, $\chi 2(285,98)=$ $218.26 ; p<.001 ; \mathrm{TLI}=.88, \mathrm{CFI}=.90, \mathrm{RMSEA}=.06, \mathrm{SRMR}$ $=.05$. On the contrary, the one domain solution, obtained a worse fit, $\chi^{2}(285,103)=360.29 ; p<.001 ;$ TLI $=.76$, $\mathrm{CFI}=.80, \mathrm{RMSEA}=.09, \mathrm{SRMR}=.06$

\section{Differential item functioning}

To ensure the validity generalization for each instrument, an item analysis was run for the mothers' sample and another one for the fathers' sample (Table 3 and Table 4).

Focusing on the Psychological Control Scale, the analysis revealed that item 5 "My Mother or Father is a person who brings up past mistakes when s/he criticizes me" was the reactive which got the same indexes in both versions, an adequate difficulty level and a good discrimination index. 
Table 3.

Item's analysis from the Psychological Control Scale (PCS-YSR) and the Psychological Control-Disrespect Scale (PCDS) Mothers'version.

\begin{tabular}{|c|c|c|c|c|c|c|c|c|c|}
\hline & \multicolumn{2}{|l|}{ Item } & \multicolumn{5}{|c|}{ Descriptive Statistics } & \multicolumn{2}{|c|}{ Fit Index } \\
\hline & & & $\mathrm{p}_{1}$ & $\mathrm{~b}$ & SE & $\mathrm{a}$ & SE & $S-\chi^{2}$ & $p_{2}$ \\
\hline PCS-YSR & V5 & $\begin{array}{l}\text { Cuando él/ella me critica, saca a la luz } \\
\text { errores qué cometí en el pasado }\end{array}$ & .48 & 0.14 & 0.09 & 1.40 & 0.21 & 4.73 & .45 \\
\hline PCS-YSR & V8 & $\begin{array}{l}\text { Si hiero sus sentimientos, me deja de ha- } \\
\text { blar hasta que hago algo que lo/la complaz- } \\
\text { ca (agrade) }\end{array}$ & .42 & 0.37 & 0.10 & 1.23 & 0.19 & 3.39 & .64 \\
\hline PCS-YSR & V3 & A menudo me interrumpe & .37 & 0.59 & 0.11 & 1.35 & 0.21 & 6.62 & .25 \\
\hline PCS-YSR & V1 & $\begin{array}{l}\text { Siempre intenta cambiar cómo me siento o } \\
\text { pienso con respecto a las cosas }\end{array}$ & .35 & 0.61 & 0.10 & 1.54 & 0.23 & 8.15 & .15 \\
\hline PCS-YSR & V7 & Evita mirarme cuando lo/la decepciono & .33 & 1.01 & 0.19 & 0.86 & 0.16 & 8.40 & .21 \\
\hline PCS-YSR & V6 & $\begin{array}{l}\text { Si no veo las cosas como él /ella las ve } \\
\text { ( si no pienso como él /ella) es menos } \\
\text { amistoso conmigo }\end{array}$ & .20 & 1.02 & 0.09 & 2.99 & 0.64 & 3.26 & .66 \\
\hline PCS-YSR & V2 & $\begin{array}{l}\text { Cambia de tema siempre que tengo algo } \\
\text { que decir }\end{array}$ & .16 & 1.47 & 0.16 & 1.68 & 0.29 & 12.75 & .05 \\
\hline PCS-YSR & V4 & $\begin{array}{l}\text { Me culpa a mí de los problemas de otros } \\
\text { miembros de la familia }\end{array}$ & .14 & 1.52 & 0.16 & 1.88 & 0.33 & 4.09 & .66 \\
\hline PCDS & V6 & Espera demasiado de mí & .52 & -0.05 & 0.12 & 0.94 & 0.16 & 3.62 & .60 \\
\hline PCDS & V7 & $\begin{array}{l}\text { A menudo injustamente me compara con } \\
\text { otros }\end{array}$ & .47 & 0.22 & 0.10 & 1.28 & 0.20 & 2.84 & .72 \\
\hline PCDS & V4 & Viola mi intimidad & .37 & 0.55 & 0.10 & 1.36 & 0.21 & 2.61 & .76 \\
\hline PCDS & V5 & $\begin{array}{l}\text { Intenta hacerme sentir culpable por } \\
\text { cualquier cosa que he hecho o qué él/ella } \\
\text { quiere que haga }\end{array}$ & .27 & 0.78 & 0.09 & 2.22 & 0.36 & 3.32 & .65 \\
\hline PCDS & V1 & Me ridiculiza o me hace de menos & .15 & 1.22 & 0.11 & 2.82 & 0.51 & 6.50 & .26 \\
\hline PCDS & V3 & No me respeta como persona & .12 & 1.44 & 0.11 & 3.73 & 1.18 & 5.80 & .33 \\
\hline PCDS & V2 & Me avergüenza en público & .10 & 1.64 & 0.18 & 1.79 & 0.31 & 3.41 & .76 \\
\hline PCDS & V8 & A menudo me ignora & .10 & 1.86 & 0.21 & 1.68 & 0.30 & 4.50 & .60 \\
\hline
\end{tabular}

Note. $p_{1}=$ Proportion of correct responses, $b=$ Difficulty Level, $a=$ Slope (Discrimination Index), $S-\chi^{2}=$ fit index, $S E=$ Standard Error, $p_{2}=$ Significance level of $S-\chi^{2}$ statistic.

Certainly, almost all items got good levels of difficulty, less than in the "Psychological Control-Disrespect Scale", father version, where item 4, "My Mother or Father is a person who violates my privacy (e.g. entering my room, going through my things, etc.)", and item 2, "My Mother or Father is a person who embarrasses me in public (e.g. in front of my friends)"; theses reactive got $b$ values higher than 2 (Table 4).

The analysis of fit index S- $\chi^{2}$ showed that items got a good fit to the underlying construct in both instruments; the significant level of S- $\chi^{2}$ values were higher than $p<.01$ (Orlando \& Reeve, 2007, Orlando \& Thissen, 2003) (Table 3 and Table 4); there was an exception with item 2 in the "Psychological Control Scale", Mother version, where the $p$ value of $\mathrm{S}-\chi^{2}$ was .05 .

To conclude, the fit index in PCS-YSR, in the mothers' sample got values $\mathrm{G} 2=221.97, p>.05$; RMSEA $=.00$. In the fathers' sample was $\mathrm{G} 2=240.52, p>.05$; $\mathrm{RMSEA}=.00$. As regards to PCDS, the fit indexes values were, in the mothers' sample, $\mathrm{G} 2=200.61, p>.05$; RMSEA $=.00$, and in the fathers', $\mathrm{G} 2=163.39, p>.05$; RMSEA $=.00$. These findings illustrate the good construct validity of both instruments.

\section{Convergent and divergent validity}

Given that the factorial structure was similar for perceptions about fathers and mothers, Pearson's correlations were performed between the PCS-YSR, PCDS, DAPCS, P-PASS and AF-self-concept (Table 5). In order to test the distribution of normality, skewness and kurtosis values in each of the variables were considered. All variables ranged from values of 2.15 to -1.78 for skewness, and 2.41 to -0.58 for kurtosis.

Correlations between Barber's scales were positive with the two DAPCS' domains, and with the subscale of P-PASS of parental control (Table 5). However, there were negative correlations between, both maternal and paternal psychological control with autonomy support and the five dimensions of self-concept. 
Table 4.

Item's analysis from Psychological Control Scale (PCS-YSR) and Psychological Control-Disrespect Scale (PCDS)

Father's version.

\begin{tabular}{|c|c|c|c|c|c|c|c|c|c|}
\hline & \multirow[b]{3}{*}{ V5 } & \multirow[t]{2}{*}{ Item } & \multicolumn{5}{|c|}{ Descriptive Statistics } & \multicolumn{2}{|c|}{ Fit Index } \\
\hline \multirow[b]{2}{*}{ PCS-YSR } & & & $\mathrm{p}_{1}$ & $\mathrm{~b}$ & $\mathrm{SE}$ & $\mathrm{a}$ & $\mathrm{SE}$ & $\mathrm{S}-\chi^{2}$ & $\mathrm{p}_{2}$ \\
\hline & & $\begin{array}{l}\text { Cuando él/ella me critica, saca a la luz errores } \\
\text { que cometí en el pasado }\end{array}$ & .35 & 0.61 & 0.10 & 1.59 & 0.24 & 10.14 & .07 \\
\hline PCS-YSR & V1 & $\begin{array}{l}\text { Siempre intenta cambiar cómo me siento o pien- } \\
\text { so con respecto a las cosas }\end{array}$ & .33 & 0.68 & 0.10 & 1.69 & 0.26 & 6.90 & .23 \\
\hline PCS-YSR & V8 & $\begin{array}{l}\text { Si hiero sus sentimientos, me deja de hablar has- } \\
\text { ta que hago algo que lo/la complazca (agrade) }\end{array}$ & .34 & 0.79 & 0.14 & 1.12 & 0.19 & 8.09 & .23 \\
\hline PCS-YSR & V3 & A menudo me interrumpe & .30 & 0.88 & 0.13 & 1.32 & 0.22 & 10.46 & .11 \\
\hline PCS-YSR & V6 & $\begin{array}{l}\text { Si no veo las cosas como él /ella las ve (si no } \\
\text { pienso como él /ella) es menos amistoso conmi- } \\
\text { go }\end{array}$ & .23 & 0.89 & 0.09 & 2.82 & 0.53 & 6.69 & .25 \\
\hline PCS-YSR & V7 & Evita mirarme cuando lo/la decepciono & .32 & 0.89 & 0.15 & 1.07 & 0.18 & 7.10 & .31 \\
\hline PCS-YSR & $\mathrm{V} 2$ & $\begin{array}{l}\text { Cambia de tema siempre que tengo algo que } \\
\text { decir }\end{array}$ & .17 & 1.31 & 0.14 & 1.81 & 0.31 & 7.17 & .31 \\
\hline PCS-YSR & V4 & $\begin{array}{l}\text { Me culpa a mí de los problemas de otros miem- } \\
\text { bros de la familia }\end{array}$ & .11 & 1.54 & 0.15 & 2.32 & 0.47 & 8.29 & .22 \\
\hline PCDS & V6 & Espera demasiado de mí & .48 & 0.14 & 0.13 & 0.88 & 0.17 & 8.87 & .11 \\
\hline PCDS & V7 & A menudo injustamente me compara con otros & .28 & 0.94 & 0.13 & 1.41 & 0.23 & 6.94 & .23 \\
\hline PCDS & V5 & $\begin{array}{l}\text { Intenta hacerme sentir culpable por cualquier } \\
\text { cosa que he hecho o qué él/ella quiere que haga }\end{array}$ & .19 & 1.00 & 0.09 & 3.21 & 0.62 & 5.41 & .25 \\
\hline PCDS & V1 & Me ridiculiza o me hace de menos & .15 & 1.19 & 0.10 & 3.16 & 0.66 & 5.26 & .26 \\
\hline PCDS & V3 & No me respeta como persona & .09 & 1.55 & 0.13 & 3.25 & 0.78 & 5.38 & .25 \\
\hline PCDS & V8 & A menudo me ignora & .14 & 1.55 & 0.17 & 1.71 & 0.30 & 6.04 & .42 \\
\hline PCDS & V4 & Viola mi intimidad & .10 & 2.12 & 0.31 & 1.29 & 0.26 & 8.55 & .20 \\
\hline PCDS & $\mathrm{V} 2$ & Me avergüenza en público & .08 & 2.20 & 0.30 & 1.48 & 0.30 & 3.77 & .71 \\
\hline
\end{tabular}

Note. $p_{1}=$ Proportion of correct responses, $b=$ Difficult Level, $a=$ Slope (Discrimination Index), $S-\chi^{2}=$ fit index, $S E=$ Standard Error, $p_{2}=$ Significance level of $S-\chi^{2}$ statistic.

Table 5

Summary of inter-correlations from PCS- YSR, PCDS, DAPCS, P-PASS and AF5

\begin{tabular}{|c|c|c|c|c|}
\hline \multirow{2}{*}{$\begin{array}{ll} & \text { Variable } \\
\text { Maternal ratings } & \end{array}$} & \multicolumn{2}{|c|}{ PCS-YSR } & \multicolumn{2}{|c|}{ PCDS } \\
\hline & Fathers & Mothers & Fathers & Mothers \\
\hline DAPCS_DPC & $.46^{* * *}$ & $.48^{* * *}$ & $.45^{* * *}$ & $.50^{* * *}$ \\
\hline DAPCS_APC & $.40^{* * *}$ & $.60^{* * *}$ & $.41^{* * *}$ & $.74^{* * *}$ \\
\hline Autonomy support_P-PASS & $-.31^{* * *}$ & $-.55^{* * *}$ & $-.31^{* * *}$ & $-.49^{* * *}$ \\
\hline Parental control_P-PASS & $.42^{* * *}$ & $.52^{* * *}$ & $.42^{* * *}$ & $.53^{* * *}$ \\
\hline \multicolumn{5}{|l|}{ Paternal ratings } \\
\hline DAPCS_DPC & $.60^{* * *}$ & $.30^{* * *}$ & $.53^{* * *}$ & $.31^{* * *}$ \\
\hline DAPCS_APC & $.65^{* * *}$ & $.43^{* * *}$ & $.69^{* * *}$ & $.51^{* * *}$ \\
\hline Autonomy support_P-PASS & $-.52^{* * *}$ & $-.44^{* * *}$ & $-.54^{* * *}$ & $-.42^{* * *}$ \\
\hline Parental control_P-PASS & $.59^{* * *}$ & $.33^{* * *}$ & $.64^{* * *}$ & $.38^{* * *}$ \\
\hline \multicolumn{5}{|l|}{ Student's Self-Concept } \\
\hline Social self-concept & -.06 & $-.18^{* * *}$ & $-21^{* * *}$ & $-.15^{* * *}$ \\
\hline Academic/labor self-concept & -.07 & $-.14^{* * *}$ & $-.13^{* *}$ & $-.18^{* * *}$ \\
\hline Emotional self-concept & -.07 & $-.15^{* * *}$ & $-13^{* * *}$ & $-.13^{* * *}$ \\
\hline Physical self-concept & $-.12 *$ & $-.13^{* * *}$ & $-.16^{* *}$ & $-.14^{* * *}$ \\
\hline Family self-concept & $-.43^{* * *}$ & $-.57^{* * *}$ & $-.51^{* * *}$ & $-.66^{* * *}$ \\
\hline
\end{tabular}

Note. PCS-YSR $=$ Psychological Control Scale, PCDS = Psychological Control-Disrespect Scale, DAPCS_DPC = DependencyOriented and Achievement-Oriented Psychological Control Scale_Dependency-Oriented psychological control, DAPCS_APC = Dependency-Oriented and Achievement-Oriented Psychological Control Scale_Achievement-Oriented psychological control, P-PASS $=$ Perceived Parental Autonomy Support Scale, AF5 = Autoconcepto Forma 5 .

$* p<.05 * * p<.01 * * * p<.001$ 
116

\section{Predictive validity}

As a final step in data analysis, a regression model was run to test the predictive power of psychological control, assessed through PCS-YSR and PCDS on the five selfconcepts. The model established considering PCS-YSR and PCDS as predictor variables and the five self-concepts as criterion variables. The strategy was to verify, first, the influence of psychological control, assessed by PCS-YSR, alone (Model 1). The fit, in this model, was not good; the TLC and CFI values did not reach the optimum cut-off point. When the psychological disrespectful control was introduced, the fit was worse (Model 2) (Table 6). Afterwards, the PCS-YSR and PCDS domains were added to the model (Model 3). Lastly, Table 6 shows that Model 3 is the most parsimonious model, and Table 7 depicts the standardized coefficients. In addition, a multiple group analysis was conducted to determine whether students' gender could moderate the relations among the variables (Model 4). The findings produced good results; it can be concluded that the model keeps along students' gender, $\Delta \chi^{2}=6.14 ; p>.05$.

Table 7 displays the significant standardized coefficients of PCS-YSR and PCDS on each self-concept. The psychological control, defined as manipulative behavior, used by mothers, has a huge impact on social, emotional and family self-concept. Findings show that there is a little difference between men and women, with regards to emotional selfconcept. Disrespectful behaviors in mothers towards their children seem to develop a lower family self-concept, both in male and female students. Concerning men, this offensive behavior could lead to lower academic/labour self-concept. Regarding psychological-manipulative control behaviors from fathers, the results were similar for men and women, regardless of gender. The social self-concept is the most affected when the father carries out behaviors such as making their son/daughter feel guilty, criticizing them, withdrawing affection when their son/daughter doesn't think like him, or pulling back when their son/daughter disappoints him. However, the psychological control-manipulative, and the father do not have an influence over self-concept in men and women. To conclude this section, it is interesting to note the percentage of explained variance on each selfconcept (Table 7). The family self-concept was explained by psychological control and disrespectful behaviors of parents in more than $57 \%$ of male students and in $43 \%$ of female students; and if the full sample is considered, the percentage raises to $49 \%$.

\section{Discussion}

This research examined the psychometric properties of the PCS-YSR and PCDS in two samples of Spanish late adolescents. Exploratory and confirmatory analysis showed a good fit for the original instruments. Likewise, one of the goals of this research was to analyze if psychological control could be defined as one dimension or as two dimensions of the same construct. PCS-YRS measures controlling parents defined as those progenitors showing manipulative behaviors whereas PCDS measures parental psychological control understood as parents showing disrespectful behaviors. EFA and CFA demonstrated that PCS-YSR and PCDS were two different scales. Both scales measured different but related dimensions of parental psychological control (Barber et al., 2012).

In sum, this research supported these two dimensions (manipulative and disrespectful psychological control behaviors), which were necessary to define a whole parental psychological control dimension, understood as students' perception about fathers' and mothers' psychological controlling behaviors. Additionally, the results of the regression model kept the need to consider both dimensions as components of the parental psychological control construct. In this sense, the different models tested confirmed that when students perceived that their parents, mother and father, showed manipulative and disrespectful behaviors towards them, their self-concept was more affected. Focusing on the standardized factor loadings for PCS-YSR and PCDS, the results were similar to Barber's et al., (2012) ones; these

Table 6

Summary of Predictive Model Analysis

\begin{tabular}{llllllll}
\hline & $\chi^{2}$ & $d f$ & $p_{\text {value }}$ & TLI-NNFI & CFI & RMSEA & RMSR \\
\hline Model 1 & 228.78 & 15 & .00 & .05 & .59 & .18 & .12 \\
Model 2 & 155.07 & 15 & .00 & .36 & .73 & .15 & .08 \\
Model $3_{\text {PCS-YSR }}$ & 7.87 & 4 & .10 & .95 & .99 & .05 & .02 \\
Model $4{ }_{\text {multigroup_gender }}$ & 14.01 & 8 & .08 & .92 & .99 & .06 & .02 \\
\hline
\end{tabular}

Note. $d f=$ degrees of freedom, TLI-NNFI =Tucker Lewis Index - Non-normed Fit Index, CFI = comparative fit index, RMSEA = Root Mean Square Error of Approximation, RMSR= Root Mean Square of Residuals. 
Table 7

Standardized regression coefficients for association PCS-YSR and PCDS and five late adolescents' self-concept

Outcomes: Student's self-concept

\begin{tabular}{|c|c|c|c|c|c|c|}
\hline \multirow{2}{*}{$\begin{array}{l}\text { Predictor } \\
\text { Maternal ratings }\end{array}$} & \multicolumn{2}{|c|}{$\begin{array}{c}\text { Full sample } \\
n=436\end{array}$} & \multicolumn{2}{|l|}{ Men } & \multicolumn{2}{|c|}{ Women } \\
\hline & & & & & & \\
\hline \multirow{3}{*}{$\begin{array}{l}\text { Psychological Control- } \\
\text { manipulative }\end{array}$} & Social & $-.17^{* * *}$ & & & Social & $-.22^{* * *}$ \\
\hline & Family & $-.15^{*}$ & Family & $-.23^{*}$ & Emotional & $-.25^{*}$ \\
\hline & Emotional & $-.14^{* *}$ & & & Physical & $-.15^{* *}$ \\
\hline Control-Disrespect & $\begin{array}{c}\text { Academic/Labor } \\
\text { Family }\end{array}$ & $\begin{array}{l}-.17^{*} \\
-.42^{* * *}\end{array}$ & $\begin{array}{c}\text { Academic/Labor } \\
\text { Family }\end{array}$ & $\begin{array}{l}-.32^{*} \\
-.60^{* * *}\end{array}$ & Family & $-.53^{* * *}$ \\
\hline \multicolumn{7}{|l|}{$\begin{array}{l}\text { Paternal ratings } \\
\text { Psychological Control- } \\
\text { manipulative }\end{array}$} \\
\hline Control-Disrespect & $\begin{array}{c}\text { Social } \\
\text { Family } \\
\text { Physical }\end{array}$ & $\begin{array}{l}-.31^{* * *} \\
-.26^{* * *} \\
-.15^{* *} \\
\end{array}$ & $\begin{array}{c}\text { Social } \\
\text { Physical }\end{array}$ & $\begin{array}{l}-.30 .^{* * *} \\
-.31^{* *}\end{array}$ & $\begin{array}{l}\text { Social } \\
\text { Family }\end{array}$ & $\begin{array}{l}-.21^{* * *} \\
-.20^{* * *}\end{array}$ \\
\hline \multicolumn{7}{|c|}{$\begin{array}{l}\text { Note. } R_{\text {Familiar }}^{2}=49 \% ; R_{\text {Social self-concept }}^{2}=8 \%, R_{\text {Emotional self-concept }}^{2}=2 \%, R_{\text {Academic/Labor self-concept }}^{2} \\
\text { Academic/Labor self-concept } \\
\text { Women. } R_{\text {Familiar }}^{2}=40 \%, R_{\text {Social self-concept }}^{2}=9 \%, R_{\text {Physical self-concept }}^{2}=9 \% . \\
*_{\text {Social self-concept }}=5 \%, R_{\text {Emotional self-concept }}^{2}=6 \% ; R_{\text {Physicial }}^{2}=2 \% . \\
*_{p}<.05 * *_{p}<.01 * * p<.001\end{array}$} \\
\hline
\end{tabular}

authors found the PCS-YSR highest loadings in items 4, 5 and 6; PCDS items 3 and 5, obtained the highest values in the five samples used. The differential item analysis support construct validity and generalization. For both versions -mothers and fathers- results were similar, and the fit indices were optimum for each item and for the whole instrument.

As it had been hypothesized, correlations between Barber's scales were positive with the two DAPCS' domains (dependency-oriented and achievement-oriented psychological control), and with the P-PASS subscale which measures parental psychological control (Mantzouranis et al., 2012; Soenens et al., 2010; Soenens et al., 2012). These results also confirmed the negative correlations between Barber's scales and the subscale of P-PASS which measures parental autonomy support. That is, when late adolescents felt that their parents manipulated and disrespected them, they thought that their sense of autonomy was not being supported. Furthermore, the size of the sample could explain the low correlations found between certain variables. Future studies, with wider samples would be necessary to confirm or reject these findings. It can be concluded that the two scales developed by Barber and colleagues appropriately measure the construct "parental psychological control" and both scales are a good complement to the
DAPCS scale (Soenens et al., 2012). This is so because the DAPCS scale measures two types of parental psychological control: dependency-oriented and achievement-oriented psychological control, but at the base of both types of psychological control are the manipulative and disrespect parental behaviors which are measured by the PCS-YRS and PCDS.

Considering the findings on predictive value of PCS-YSR and PCDS on self-concepts, especially the high values on family self-concept, it must be concluded that avoiding parental psychological controlling behaviors is of great importance. Results were similar to those obtained in other research which confirmed the influence of psychological control, measured through PCS-YSR, on other internalizing problems which are different from self-concept (Aunola et al., 2013; Barber et al., 2005; Lansford et al., 2014; Mabbe et al., 2016; Rogers et al., 2003; 2020), particularly on depressive symptoms (Ahmad \& Soenens, 2010; Barber 1996, Barber et al., 2005; Rogers et al., 2020; Romm et al., 2020; Rudy et al., 2008), low academic perfomance (Lu et al., 2018), fear of failure (Deneault et al., 2020), under-eating behaviors (Romm and Metzger, 2018; Romm et al., 2020), and substance abuse (Romm and Metzger, 2018; Romm et al., 2020).

In this sense, this study complemented the research by Bean and Northrup (2009), Özdemir (2012), and 
Soenens et al., (2005). So, in those studies it was found that perceived parental psychological control, measured through PCS-YSR, had an influence on the assessment that a person made of himself/herself, that is, on their self-esteem. On the other hand, this study concluded that parental psychological control also influenced negatively on selfconcept. During adolescence, the expectations of others, comparisons, and personal referents can exert a strong pressure and create insecurities in adolescents. For this reason, parents use psychological controlling behaviors to create an environment in which adolescents are vulnerable to develop a negative self-concept and a low self-esteem.

Parental psychological control had significant influence (weight) on two self-concept domains for the full sample ratings: family and social self-concept. Furthermore, by maternal ratings, disrespectful psychological control behaviors, measured through PCDS, also had an influence on academic/labor self-concept, and fathers' ratings on the physical one. In this way, the emotional self-concept was influenced by maternal psychological control in the full sample and specifically in the women's sample. In this sense, it is necessary to highlight the influence of parental psychological control on the development of family self-concept. This influence may occur because it is important for children and adolescents to feel safe and happy at home. So, when the family environment is controlling, adolescents can feel dissatisfied and frustrated and they may be more vulnerable to develop a negative sense of family belonging.

In relation to the full sample and when this was divided into men and women late adolescents, an unexpected conclusion was also drawn. So, manipulative paternal behavior, measured through PCS-YRS, did not influenced social self-concept. Nevertheless, this result was not found for maternal ratings and neither for PCDS (maternal and paternal ratings). In both cases, there were negative correlations between perceived parental psychological control and social self-concept. More research is needed to understand this unpredictable conclusion. One hypothesis to explain this finding could be the meanings that social self-concept has. García and Musitu (1999) identified two dimensions in this self-concept, one regarding the social network person and his/her skill to keep it and spread out it; and the second, related to the person's social competences, for instance, if he/she is outgoing, cheerful, and so on. With respect to the first meaning, it could be hypothesized that when young people perceive much criticism from their fathers to make them feel guilty, these youngsters try to develop more social relationships outside the home, as a protective factor. Furthermore, it would be very interesting to assess if these relationships that the youth develop as a result of a huge psychological-manipulative control practiced by their fathers, become independent social relationships. One of the outcomes of a huge psychological control is the concern about close relationships (Ahmad and Soenens, 2010).

In the current study gender differences were found about the influence of psychological controlling mothers and fathers on men's and women's self-concept. Results obtained in other studies about the influence of parental gender on different outcomes were mixed. So, in some studies, there were no gender differences (Arim and Shapka, 2008), whereas in other studies a greater influence of paternal psychological control was found (Casas et al., 2006; Lansford et al., 2014; Rogers et al., 2003). In the present research, results were different because maternal manipulative and disrespectful behaviors negatively correlated with adolescent's family and academic/labor self-concept, both in women and men. Furthermore, maternal psychological control also correlated negatively, only in men, with family self-concept; and in women, with social, emotional and physical self-concept, whereas each participant had to assess their parents (mother and father) by responding some questions about their progenitors. Paternal psychological control did not have an influence on any self-concept. In sum, mothers and fathers were predictors of adolescents' self-concept. Nevertheless, findings from the current study also demonstrated that there were differences in how mothers' and fathers' controlling parenting was linked to self-concept development. In this sense, perceived maternal psychological control exerted more influence on self-concept than perceived paternal psychological control. Thus, traditionally, mothers have been more involved in children and adolescents' development. For this reason, it is logical to conclude that mothers have a greater influence on children's and adolescents' adjustment.

In summary, this study found support for the reliability and validity of the PCS-YRS and PCDS in the Spanish context. It also contributed to extending previous research which concluded that controlling parents had a negative influence on adolescents' psychological well-being. The study extends previous research in Spain, a country which has different linguistic and cultural backgrounds from Barber's and other research samples. From SDT, parents who are perceived as controllers impede the satisfaction of three basic psychological needs: autonomy, competence, and relatedness. It is widely agreed that avoiding these behaviors in all cultural contexts is necessary (Soenens \& Vansteenkiste 2010). For this reason, it is necessary to analyze the generality of controlling parenting and its effects on adolescents across different cultural contexts, and this research has contributed thereof. 


\section{References}

Ahmad, I., \& Soenens, B. (2010). Perceived maternal parenting as a mediator of the intergenerational similarity of dependency and self-criticism: a study with Arab Jordanian adolescents and their mothers. Journal of Family Psychology, 24, 756-765. https://doi.org/10.1037/a0021508

Alto, M., López, J., \& Benavente, A. (2013). Un sistema de clasificación de los diseños de investigación en psicología. Anales de Psicología, 29, 1038-1059. https://doi. org/10.6018/analesps.34.1.262131

American Psychological Association, American Educational Research Association \& National Council on Measurement in Education (1985). Standards of educational and psychological testing. Washington, DC: American Psychological Association.

Arim, R.G., \& Shapka, J. (2008). The impact of pubertal timing and parental control on adolescents' problem behaviors. Journal of Youth and Adolescence, 37, 445-455. https://doi. org/10.1007/s10964-006-9158-y

Aunola, K., Tolvanen, A., Viljaranta, J., \& Nurmi, J.E. (2013). Psychological control in daily parent-child interactions increases children's negative emotions. Journal of Family Psychology, 27, 453-462. https://doi.org/10.1037/a0032891

Barber, B. (1996). Parental psychological control: revisiting a neglected construct. Child Development, 67, 3296-3319. https://doi.org/10.1111/j.1467-8624.1996.tb01915.x

Barber, B., \& Harmon, E.L. (2002). Violating the self: parental psychological control of children and adolescents. In B.K. Barber (Ed.), Intrusive parenting: How psychological control affects children and adolescents (pp. 15-52). Washington, DC: American Psychological Association.

Barber, B., Stolz, H., Olsen, J.A., Collins, W.A., \& Burchinal. M. (2005). Parental support, psychological control, and behavioral control: Assessing relevance across time, culture, and method. Monographs of the Society for Research in Child Development, 70, 1-147. https://www.jstor.org/ stable/3701442

Barber, B., Xia, M., Olsen, J., McNeely, C., y Bose, K. (2012). Feeling disrespected by parents: refining the measurement and understanding of psychological control. Journal of Adolescence, 35, 273-287. https://doi.org/10.1016/j. cub.2017.05.064

Bean, R., Barber, B., y Crane, D. (2006). Parental support, behavioral control, and psychological control among African American youth. Journal of Family Issues, 27, 1335-1355. https://doi.org/10.1111/j.1467-8624.1996.tb01915.x

Bean, R. A., \& Northrup, J. C. (2009). Parental psychological control, psychological autonomy, and acceptance as predictors of self-esteem in Latino adolescents. Journal of Family Issues, 30, 1486-1504. https://doi. org/10.1177/0192513X09339149

Blossom, J.B., Fite, P. J., Frazer, P. J., Cooley, J. L., \& Evans, S. (2016). Parental psychological control and aggression in youth: Moderating effect of emotion dysregulation. Journal of Applied Developmental Psychology, 44, 12-20. https:// doi.org/10.1016/j.appdev.2016.02.006

Casas, J.F., Weigel, S.M., Crick, N.R., Ostrov, J.M., Woods, K.E., Jansen, E.A., \& Huddleston-Casas, C.A. (2006). Early parenting and children's relational and physical aggression in the preschool and home contexts. Applied Developmental Psychology, 27, 209-227. https://doi.org/10.1016/j. appdev.2006.02.003

Cui, L., Morris, A.S., Criss, M. M., Houltberg, B. J., \& Silk, J. (2014). Parental psychological control and adolescent adjustment: The role of adolescent emotion regulation. Parenting, 14, 47-67. https://doi.org/10.1080/15295192.20 14.880018

Deneault, A., Gareau, A., Bureau, J-F., Gaudreau, P., \& Lafontaine, M-F. (2020). Fear of failure mediates the relation between parental psychological control and academic outcomes: A latent mediated-moderation model of parents' and children's genders. Journal of Youth and Adolescence, 49, 1567-1582. https://doi.org/10.1007/ s10964-020-01209-X

Ferrando, P. J., \& Anguiano-Carrasco, C. (2010). El análisis factorial como técnica de investigación en psicología. [Factor analysis as a research technique in psychology]. Papeles del Psicólogo, 31, 18-33. https://www.redalyc.org/ pdf/778/77812441003.pdf

Ferrando, P.J., \& Lorenzo-Seva, U. (2017). Program Factor at 10: origins, development and future directions. Psicothema, 29, 236-240. http://dx.doi.org/10.7334/psicothema2016.304

García, F., \& Musitu, G. (1999). AF5. Autoconcepto Forma 5. Manual. [AF5. Self-concept. Manual. 5 Version] Madrid: TEA Ediciones.

García-Pérez, O., Rodríguez-Menéndez, C., Torío-López, S., \& Pérez-Rodríguez, S. (2019). Validation of the DependencyOriented and Achievement-Oriented Psychological Control Scale (DAPCS) in a Spanish-speaking late adolescent sample. Anales de Psicología, 35, 453-463. https://doi. org/10.6018/analesps.35.3.329991

Hambleton, R., Merenda, P., \& Spielberger, Ch. (2005). Adapting Educational and Psychological Tests for CrossCultural Assessment. New York: Psychology Press.

Hunter, S., Barber, B. K., \& Stolz, H. E (2015). Extending knowledge of parents' role in adolescent development: The mediating effect of self-esteem. Journal of Child and Family Studies, 24, 2474-2484. https://doi.org/10.1007/ s10826-014-0050-1

Lorenzo-Seva, U. (1999). Promin: A method for oblique factor rotation. Multivariate Behavioral Research, 34, 347-365. https://doi.org/10.1207/S15327906MBR3403_3

Lansford, J.E., Laird, R.D., Pettit, G.S., Bates, J.E., \& Dodge, K. (2014). Mothers' and fathers' autonomy-relevant parenting: longitudinal links with adolescents' externalizing and internalizing behavior. Journal of Youth and Adolescence, 43, 1877-1889. https://doi.org/10.1007/s10964-013-0079-2 
Loukas, A., Paulos, S.K., \& Robinson, S. (2005). Early adolescent social and overt aggression: Examining the roles of social anxiety and maternal psychological control. Journal of Youth and Adolescence, 34, 335-345. https://doi. org/10.1007/s10964-005-5757-2

Lu, M., Walsh, K., White, S., \& Shield, P. (2018). Influence of perceived maternal psychological control on academic performance in Chinese adolescents: Moderating roles of adolescents' age, gender, and filial piety. Marriage \& Family Review, 54, 50-63. https://doi.org/10.1080/01494929.2017 .1347548

Mabbe, L., Soenens, B., Vansteenkiste, M., \& Van Leeuwen, K. (2016). Do personality traits moderate relations between psychologically controlling parenting and problem behavior in adolescents? Journal of Personality, 84, 381-392. https://doi.org/10.1111/jopy.12166

Mageau, G. A., Ranger, F., Joussemet, M., Koestner, R., Moreau, E., \& Forest, J. (2015). Validation of the Perceived Parental Autonomy Support Scale (P-PASS). Canadian Journal of Behavioural Science, 47, 251-262. http://dx.doi. org/10.1037/a0039325

Mantzouranis, G.; Zimmermann, G.; Mahaim, E.B.; \& Favez, N. (2012). A further examination of the distinction between dependency-oriented parental psychological control and achievement-oriented parental psychological control: Psychometric properties of the DAPCS with French-speaking late adolescents. Journal of Child and Family Studies, 21, 726-733. https://doi.org/10.1007/s10826-011-9525-5

Márquez, C.V., Villareal, L., Verdugo, J.C., \& Montes, R. (2014). Control psicológico parental y violencia escolar entre adolescentes en una muestra mexicana. International Journal of Developmental and Educational Psychology [Parental psychological control and school violence among adolescents in a Mexican sample], 2, 257-262. http://dx.doi. org/10.17060/ijodaep.2014.n2.v1.031

Muthén, L. K., \& Muthén, B. O. (1998-2012). Mplus user's guide (7th Ed.). Los Angeles: Muthén \& Muthén.

Orlando, M., \& Reeve, B. (2007). Applying item response theory (IRT) modeling to questionnaire development, evaluation, and refinement. Quality of Life Research, 16, 5-18. https://doi.org/10.1007/s11136-007-9198-0

Orlando, M., \& Thissen, D. (2003). Further investigation of the performance of $\mathrm{S}-\mathrm{X}^{2}$ : An item fit index for use with dichotomous item response theory models. Applied Psychological Measurement, 27, 289-298. https://doi. org $/ 10.1177 / 0146621603027004004$

Özdemir, Y. (2012). Parental behavioral and psychological control relationships to self-esteem, life satisfaction, depression, and antisocial behaviors. International Journal of Human Sciences, 9, 1581-1590. https://core.ac.uk/download/pdf/268072747.pd

Rogers, K.N., Buchanan, C., \& Winchell, M. (2003). Psychological control during early adolescence: links to adjustment in different parent/adolescent dyads. Journal of Early Adolescence, 23, 349-383. https://doi. org/10.1177/0272431603258344

Rogers, K.N., Padilla-Walker, L., McLean, R.D., \& Hurst, J. (2020). Trajectories of perceived parental psychological control across adolescence and implications for the development of depressive and anxiety symptoms. Journal of Youth and Adolescence, 49, 136-149. https://doi.org/10.1007/ s10964-019-01070-7

Romm, K.F., \& Metzger, A. (2018). Parental psychological control and adolescent problem behaviors: The role of depressive symptoms. Journal of Child and Family Studies, 27, 2206-2216. https://doi.org/10.1007/s10826-018-1064-x

Romm, K.F., Metzger, A., \& Alvis, L. M. (2020). Parental psychological control and adolescent problematic outcomes: a multidimensional approach. Journal of Child and Family Studies, 29, 195-207. https://doi.org/10.1007/s10826-019-01545-y

Rudy, D., Awong, T., \& Lambert, M. (2008). Parental psychological control and authoritarianism in Chinese-Canadian and European-Canadian cultural groups: their meanings and implications for university students' adjustment. Journal of Comparative Family Studies, 39, 471-490. https://doi. org/10.3138/jcfs.39.4.471

Scientific Software International (2017). IRTPRO guide. https://vpgcentral.com/wp-content/uploads/2020/06/ IRTPROGuide.pdf

Soenens, B., Park, S-Y., Vansteenkiste, M., \& Mouratidis, A. (2012). Perceived parental psychological control and adolescents depressive experiences: a cross-cultural study with Belgian and South-Korean adolescents. Journal of Adolescence, 35, 261-272. https://doi.org/10.1016/j. cub.2017.05.064

Soenens, B., y Vansteenkiste, M. (2010). A theoretical upgrade of the concept of parental psychological control: proposing new insights on the basis of self-determination theory. Developmental Review, 30, 74-99. https://doi.org/10.1016/j. dr.2009.11.001

Soenens, B., Vansteenkiste, M., Goossens, L., \& Duriez, B. (2008). The intervening role of relational aggression between psychological control and friendship quality. Social Development, 17, 661-681. https://doi. org/10.1111/j.1467-9507.2007.00454.x

Soenens, B., Vansteenkiste, M., \& Luyten, P. (2010). Toward a domain-specific approach to the study of parental psychological control: Distinguishing between dependency-oriented and achievement-oriented psychological control. Journal of Personality, 78, 217-256. https://doi. org/10.1111/j.1467-6494.2009.00614.x

Soenens, B., Vansteenkiste, M., Luyten, P., Duriez, B., \& Goossens, L. (2005). Maladaptive perfectionism self-representations: the mediational link between psychological control and adjustment. Personality and Individual Differences, 38, 487-498. https://doi.org/10.1016/j.paid.2004.05.008. 